\title{
Prolactinomas, Cushing's disease and acromegaly: debating the role of medical therapy for secretory pituitary adenomas
}

\author{
Beverly MK Biller*1, Annamaria Colao², Stephan Petersenn³, Vivien S Bonert ${ }^{4}$ and Marco Boscaro 5
}

\begin{abstract}
Pituitary adenomas are associated with a variety of clinical manifestations resulting from excessive hormone secretion and tumor mass effects, and require a multidisciplinary management approach. This article discusses the treatment modalities for the management of patients with a prolactinoma, Cushing's disease and acromegaly, and summarizes the options for medical therapy in these patients.

First-line treatment of prolactinomas is pharmacotherapy with dopamine agonists; recent reports of cardiac valve abnormalities associated with this class of medication in Parkinson's disease has prompted study in hyperprolactinemic populations. Patients with resistance to dopamine agonists may require other treatment. First-line treatment of Cushing's disease is pituitary surgery by a surgeon with experience in this condition. Current medical options for Cushing's disease block adrenal cortisol production, but do not treat the underlying disease. Pituitary-directed medical therapies are now being explored. In several small studies, the dopamine agonist cabergoline normalized urinary free cortisol in some patients. The multi-receptor targeted somatostatin analogue pasireotide (SOM230) shows promise as a pituitary-directed medical therapy in Cushing's disease; further studies will determine its efficacy and safety. Radiation therapy, with medical adrenal blockade while awaiting the effects of radiation, and bilateral adrenalectomy remain standard treatment options for patients not cured with pituitary surgery. In patients with acromegaly, surgery remains the first-line treatment option when the tumor is likely to be completely resected, or for debulking, especially when the tumor is compressing neurovisual structures. Primary therapy with somatostatin analogues has been used in some patients with large extrasellar tumors not amenable to surgical cure, patients at high surgical risk and patients who decline surgery. Pegvisomant is indicated in patients who have not responded to surgery and other medical therapy, although there are regional differences in when it is prescribed. In conclusion, the treatment of patients with pituitary adenomas requires a multidisciplinary approach. Dopamine agonists are an effective first-line medical therapy in most patients with a prolactinoma, and somatostatin analogues can be used as first-line therapy in selected patients with acromegaly. Current medical therapies for Cushing's disease primarily focus on adrenal blockade of cortisol production, although pasireotide and cabergoline show promise as pituitary-directed medical therapy for Cushing's disease; further long-term evaluation of efficacy and safety is important.
\end{abstract}

\section{Review}

Pituitary adenomas are classified according to the characteristic cell type from which the adenoma is derived, and include prolactinomas, somatotroph, corticotroph, gonadotroph, thyrotroph and null-cell (nonsecretory) adenomas. Morbidity associated with pituitary adenomas

\footnotetext{
* Correspondence: bbiller@partners.org

1 Neuroendocrine Clinical Center, Massachusetts General Hospital, Boston, USA Full list of author information is available at the end of the article
}

results from mass effects of the tumor and/or the effects of excessive hormone secretion [1]. Estimates of the prevalence of pituitary adenomas in the general population vary greatly. Autopsy and radiological series have suggested that small pituitary tumors may be present in as many as one in every six people, although these series include a large proportion of lesions that are not clinically significant (incidentalomas) [2]. The prevalence of clinically relevant pituitary adenomas in a recent Belgian 
study was found to be 1 per 1064 individuals [3], which is 3.5-5 times higher than previously reported estimates of clinically relevant adenomas; prolactinomas were most common (66\%), followed by null-cell adenomas (14.7\%), somatotroph adenomas (13.2\%) and corticotroph adenomas (5.9\%) [3].

The aim of this article is to review the treatment modalities for the management of patients with the three most frequent hormone-producing tumors: prolactinomas, corticotroph adenomas (Cushing's disease) and somatotroph adenomas (acromegaly), and to summarize the medical therapy available and under investigation in these patients.

\section{Management of prolactinomas}

Prolactinomas are benign prolactin-producing pituitary adenomas. In women, the symptoms of hyperprolactinemia include infertility, menstrual irregularities, amenorrhea, galactorrhea, reduced libido and vaginal dryness, while in men they include impotence, reduced libido and infertility. If the tumor is large (a tumor with a diameter of $>1 \mathrm{~cm}$ is classified as a macroadenoma), visual field defects and headache may be the presenting features. Therefore, patients requiring therapy for prolactinomas can be divided into two groups: those requiring therapy for the symptoms of hyperprolactinemia and those requiring treatment for the effects of tumor burden [4], although some patients have both hyperprolactinemia and mass effects, while others may have neither characteristic and may not need treatment.

The goal of treatment for most patients with prolactinomas is restoration of normal prolactin secretion if there are symptoms directly caused by prolactin excess, and prevention of hormonal/metabolic consequences (eg hypogonadism and osteoporosis) [5]. In patients with large tumors compromising the neurovisual apparatus (which represents the minority of cases), a decrease in tumor size is also a goal of treatment.

Current therapeutic options for patients with prolactinomas include observation, medical therapy with dopamine agonists (eg bromocriptine, cabergoline), transsphenoidal or transcranial surgery and conventional or stereotactic radiotherapy.

Surgery is generally reserved for patients who do not respond to medical therapy, patients with unstable pituitary hemorrhage or pregnant patients with progressive tumor enlargement not responding to dopamine agonist therapy. It may also be used in patients with contraindications to dopamine agonist use, such as those patients requiring psychiatric medications that work through the dopaminergic system. Transsphenoidal surgery is the surgical method of choice, with success rates in centers with experienced neurosurgeons (based on normalization of prolactin levels) of approximately $75 \%$ in patients with microprolactinomas and 34\% in patients with macroprolactinomas [4]. Transcranial surgery is rarely performed, and is indicated in patients with tumors inaccessible via the transsphenoidal route. Radiotherapy is typically reserved for patients with large tumors jeopardizing adjacent structures who have not responded to medical or surgical treatment. Normalization of prolactin levels after radiotherapy is achieved in about one-third of patients, and the main complication is radiotherapy-induced hypopituitarism [4].

\section{Medical treatment of prolactinomas}

Prolactin secretion is regulated by the inhibitory signal of dopamine, acting via the dopamine $\mathrm{D}_{2}$ receptor [4]. Dopamine agonists have been used for the treatment of prolactinomas for over 25 years, and are widely considered the first-line therapy in patients with prolactinomas. Bromocriptine was the first dopamine agonist available for the treatment of prolactinomas, but others with a longer half-life, such as pergolide, quinagolide, and cabergoline, have since become available (although pergolide and quinagolide are not available in the US). The most extensive experience has been with bromocriptine, although cabergoline is now widely used. In most patients with prolactinomas, treatment with dopamine agonists normalizes prolactin levels, restores gonadal function and fertility, and reduces the size of the tumor. In patients with microprolactinomas, macroprolactinomas or idiopathic hyperprolactinemia, normal prolactin secretion was achieved in $76 \%$ of 997 patients treated with bromocriptine, $87 \%$ of 98 patients who received pergolide, and $89 \%$ of 612 cabergoline-treated patients [6]. With respect to the efficacy of this class of medication on tumor reduction in patients with macroprolactinomas, cabergoline appears to be the most effective, although there have not been direct comparisons. In three separate studies in patients with macroprolactinomas who received 12-27 months of firstline therapy with dopamine agonists [7-9], tumor reduction of more than $50 \%$ was seen in $64 \%, 86 \%$ and $96 \%$ of patients treated with bromocriptine, pergolide and cabergoline, respectively (Table 1 ).

Although first-line therapy with dopamine agonists is widely considered the preferred first-line treatment in patients with prolactinomas, a definitive cure has been considered possible only with surgery or, rarely, surgery plus radiotherapy. In patients successfully treated with dopamine agonists as primary therapy, it has been unclear if the withdrawal of dopamine agonists is effective and safe [10]. However, Colao et al have recently evaluated the long-term effects of dopamine-agonist withdrawal in patients who received cabergoline as firstline therapy, and showed that cabergoline can be safely withdrawn in patients who have achieved normal prolactin levels and have no evidence of residual tumor [11]. Patients in this study had nontumoral hyperprolactine- 
Table 1: Effects of first-line therapy with bromocriptine, pergolide or cabergoline on tumor size and prolactin levels in patients with macroprolactinomas

\begin{tabular}{lccc}
\hline & Bromocriptine $(\mathbf{n}=\mathbf{2 7})$ & Pergolide $(\mathbf{n}=\mathbf{2 2})$ & Cabergoline $(\mathbf{n}=\mathbf{2 6})$ \\
\hline Baseline prolactin $(\mu \mathrm{g} / \mathrm{L})$ & 2260 & 2938 & 1013 \\
Normalized prolactin (\% of patients) & 66 & 68 & 100 \\
$\geq 50 \%$ tumor reduction (\% of patients) & 64 & 86 & 96 \\
Duration of treatment (months) & 12 & 27 & 24 \\
\hline
\end{tabular}

mia $(\mathrm{n}=25)$, microprolactinomas $(\mathrm{n}=105)$ or macroprolactinomas $(\mathrm{n}=75)$ at baseline, and had been receiving primary therapy with cabergoline $0.25-3.5 \mathrm{mg} /$ week for 24-75 weeks. Withdrawal of cabergoline was considered if patients had normal prolactin levels and either no tumor visible by MRI or at least $50 \%$ reduction in tumor volume. The Kaplan-Meier estimated rate of recurrence of hyperprolactinemia 5 years after cabergoline withdrawal was low in patients who had a tumor at baseline and achieved tumor disappearance, and the recurrence rate did not differ significantly between patients with nontumoral hyperprolactinemia (24\%), microprolactinomas (26.2\%) or macroprolactinomas (32.6\%). Recurrence of hyperprolactinemia was higher in patients still presenting small remnant tumors on MRI (41.5\% in microand $77.5 \%$ in macroprolactinomas). However, in no case of biochemical recurrence did the tumor regrow or symptoms reappear; therapy was reinitiated when prolactin rose [11]. An additional analysis of estimated rates of recurrence at 7 years showed remission rates in patients with small remnant tumors was much lower in patients with macroprolactinomas than in patients with microprolactinomas $(0 \%$ vs $20 \% ; P<0.0001)$ [4]. Furthermore, Cox regression analysis determined that tumor diameter on withdrawal of cabergoline is the major determinant of recurrent hyperprolactinemia [4]. These results show that cabergoline can be safely withdrawn in patients with normalized prolactin levels and no evidence of tumor, although patients should be closely monitored upon withdrawal of therapy, particularly those patients with macroprolactinomas in whom renewed growth of the tumor may compromise vision. Whether "drug holidays" should be advised in patients with a substantial decrease in tumor size, given the recent concern about the effects of cabergoline on cardiac values, is not yet clear.

\section{Safety of dopamine agonists}

The most common adverse effects associated with dopamine agonists are nausea and vomiting $(\sim 30 \%)$, headache $(\sim 30 \%)$, and dizziness $(\sim 25 \%)$. Although the type of adverse events associated with different dopamine agonists are similar, the incidence of these events is lower with cabergoline and generally less severe than those associated with bromocriptine or pergolide. Withdrawal of cabergoline therapy because of adverse events is reported in less than $3 \%$ of patients, compared with about $12 \%$ of patients treated with bromocriptine [12].

Of concern are recent reports describing the occurrence of valvular insufficiency in patients treated with cabergoline or pergolide for Parkinson's disease. These studies showed that the use of cabergoline and pergolide in patients with Parkinson's disease is associated with an approximately 5-fold increased risk of newly diagnosed cardiac valve regurgitation $[13,14]$.

There have been nine recently published studies that evaluated the prevalence of cardiac valve regurgitation in a total of 608 patients with prolactinomas who received long-term cabergoline treatment [15-23]. Eight of the nine studies showed no evidence of clinically relevant valvular regurgitation after prolonged cabergoline treatment [16-23], although three of the eight studies did show an increased prevalence of mild tricuspid regurgitation in cabergoline-treated patients $[16,20,23]$. However, a significant increase in moderate tricuspid regurgitation was seen with cabergoline treatment compared with controls in an observational, case-control study by Colao et al. [15] that compared cardiac parameters in 50 patients with prolactinomas treated with long-term cabergoline therapy (median 6.2 years; range 1.1-10.7 years), 50 control patients and 20 patients with de novo prolactinomas. Chronic cabergoline treatment did not induce regurgitation of mitral, aortic or pulmonic valves, but an increased prevalence of moderate tricuspid regurgitation was seen in treated patients compared with controls (54\% vs $18 \%$; $P$ $<0.0001)$ and de novo patients $(54 \%$ vs $0 \% ; P<0.001)$. Tricuspid regurgitation was twice as frequent in patients with a cumulative cabergoline dose of more than $280 \mathrm{mg}$ than in patients treated with lower cumulative cabergoline doses [15].

A recent meta-analysis [24] that pooled results from six of the studies $[15,16,19-22]$ showed that patients treated with cabergoline were at increased risk of tricuspid regurgitation than control patients, with a prevalence ratio of 1.40 [95\% CI 1.17-1.67].

Results from these studies do not provide a definitive answer, and long-term investigation of this issue will be important. Some centers suggest echocardiography fol- 
low-up studies in patients with prolactinomas treated with higher doses of cabergoline or other ergot-derived drugs.

\section{Resistance to dopamine agonists}

Although dopamine agonists are an effective treatment for most patients with prolactinomas, some patients do not achieve a satisfactory response. Resistance to dopamine agonists can be defined as a failure to achieve normalization of prolactin levels or no reduction in tumor size after $12-24$ months of bromocriptine $15 \mathrm{mg} /$ day or cabergoline $0.5 \mathrm{mg} /$ day [6,25-27]; most cases of resistance to dopamine agonists can be considered partial resistance [28]. Approximately $24 \%$ and $11 \%$ of patients demonstrate resistance to bromocriptine and cabergoline, respectively [4]. In patients demonstrating possible resistance to a particular dopamine agonist, increasing the dose of that agent, as tolerated, may be effective as long as there is a continuing step-wise decrease in prolactin level with each step-wise increase in dose. Switching to another agent may be effective, but patients with resistant adenomas will usually require surgery, with or without radiotherapy, if control of a large lesion is needed.

A possible future medical therapy for patients with prolactinomas resistant to dopamine agonists is the multireceptor targeted somatostatin analogue pasireotide (SOM230). In contrast to GH-secreting pituitary adenomas which express predominantly somatostatin receptor subtypes sst $_{2}$ and sst $_{5}$, prolactinomas express primarily sst ${ }_{1}$ and sst $_{5}$. Unlike octreotide, which has high affinity for sst $_{2}$, pasireotide has a multi-receptor binding profile, with affinity for sst $_{1,2,3}$ and sst $_{5}$. An in vitro study in prolactinomas cells has demonstrated a stronger inhibition of prolactin with pasireotide than with octreotide, and that the inhibition of prolactin release was related to the expression level of sst ${ }_{5}$ [29]. Studies with pasireotide have not yet been conducted in patients with prolactinomas.

Because prolactinomas express both $\mathrm{D}_{2}$ and sst ${ }_{5}$ receptors, there is a rationale for the use of chimeric $\mathrm{D}_{2} / \mathrm{sst}_{5}$ agonists such as BIM23A760, which has high sst ${ }_{2}$ and $\mathrm{D}_{2}$ activity and moderate sst $_{5}$ activity [30,31]. A recent in vitro study of primary cultures of ten prolactinomas (six responsive to dopamine agonists and four resistant to dopamine agonists) showed that BIM 23A760 and cabergoline produced a similar partial inhibition of prolactin secretion [32].

\section{Conclusions}

First-line treatment of patients with prolactinomas is pharmacotherapy with dopamine agonists. In some centers with expert pituitary surgeons, selected patients with microprolactinomas may be offered surgery based on the high likelihood of definitive cure, although there are regional differences in how frequently surgery is advised.
Whether an increased risk for tricuspid regurgitation associated with cabergoline, especially at higher doses and with longer treatment periods, should be investigated carefully. Patients fully responsive to dopamine agonists who have achieved tumor disappearance can be considered for withdrawal from the drug with careful follow up. A small subset of patients with macroprolactinomas that are less responsive to dopamine agonists may require more aggressive treatment with surgery and/or radiotherapy if tumor location or growth rate raises concerns about compromise of adjacent neurological structures.

\section{Management of Cushing's disease}

Cushing's disease is caused by excessive secretion of adrenocorticotrophic hormone (ACTH) by a pituitary corticotroph adenoma resulting in enhanced cortisol secretion from the adrenal glands. Features of hypercortisolism include weight gain, severe fatigue and muscle weakness, high blood pressure, depression, cognitive impairment, purplish skin striae, hyperpigmentation, loss of libido, impaired glucose metabolism, hirsutism, acne, and menstrual disorders [33,34]. Chronic hypercortisolism is associated with an increased incidence of systemic arterial hypertension, diabetes mellitus, central obesity, hyperlipidemia and hypercoagulability [33]. Indeed, $20-50 \%$ of the patients with Cushing's disease have overt diabetes mellitus, whereas impaired glucose tolerance is present in $30-60 \%$ of patients [35]. Cushing's disease is associated with increased mortality, largely because of cardiovascular complications, including coronary heart disease, congestive heart disease and cerebrovascular events [36].

Treatment goals in Cushing's disease include the reversal of clinical features, the normalization of cortisol levels with minimal morbidity while preserving pituitary function, and long-term disease control without recurrence. In the small number of patients with macroadenomas, removal of the tumor mass is another treatment goal. The initial treatment of choice for Cushing's disease is generally selective pituitary adenomectomy by an experienced, dedicated pituitary surgeon. Second-line therapy includes more radical surgery, radiation therapy, including stereotactic radiosurgery, medical therapy and bilateral adrenalectomy [37,38] Cure rates in patients with Cushing's disease 10 years after pituitary surgery or radiotherapy are approximately $77 \%$ and $55 \%$, respectively [39]. Although bilateral adrenalectomy is a definitive treatment providing immediate control of hypercortisolism, patients require lifelong glucocorticoid and mineralocorticoid replacement therapy, and up to $25 \%$ of patients develop Nelson's syndrome or at least regrowth of the underlying pituitary adenoma [40]. Nelson's syndrome is the aggressive growth of a pituitary corticotroph adenoma after bilateral adrenalectomy, and is associated 
with symptoms such as skin hyperpigmentation, headache and visual impairment, which arise due to the mass effect of the tumor and increased ACTH secretion [41]. Close monitoring by regular MRI scans and measurement of plasma ACTH levels should be undertaken to detect the occurrence of corticotroph tumor progression. Early detection offers the possibility of cure by surgery (microadenoma) or radiotherapy (invasive adenomas).

Currently, there are no curative medical therapies available for Cushing's disease. The most commonly used agents reduce cortisol levels via inhibition of steroidogenesis in the adrenal glands and, thus, do not target the underlying cause of the disease. Adrenal-directed therapy (eg ketoconazole and metyrapone) is generally used in the preoperative preparation of patients with severe disease, or in patients awaiting a response to radiation therapy.

\section{Adrenal-directed therapy}

Ketoconazole and metyrapone are the most commonly used steroidogenesis inhibitors for the treatment of Cushing's disease. As reviewed by Miller and Crapo [42], $80 \%$ of 72 patients with Cushing's disease treated with ketoconazole $600-1200 \mathrm{mg} /$ day achieved normalization of urinary free cortisol (UFC) levels. A recent retrospective analysis of the long-term hormonal effects and tolerance of ketoconazole has been conduced in 38 patients with Cushing's disease, with a mean follow-up of 23 months. The data demonstrate good tolerability and effective control, particularly in patients for whom surgery is contraindicated, or delayed during the investigation of an occult adenoma [43].

In 53 patients with Cushing's disease treated for 1-16 weeks with metyrapone 750-6000 mg/day, 75\% achieved normalization of mean daily plasma cortisol [44]. However, there is little prospective data on the long-term use of steroidogenesis inhibitors, and adverse effects limit their therapeutic use in some patients. Adverse effects associated with ketoconazole include abnormal liver tests (15\%), gynecomastia (13\%), gastrointestinal effects $(8 \%)$, edema (6\%), and skin rash (2\%) [42], whereas adverse events associated with metyrapone doses $>2$ g/day include dizziness and ataxia (15\%), nausea (5\%), skin rash (4\%), edema (8\%) and hirsutism (70\%) [44].

Mitotane and etomidate are also sometimes used in the treatment of Cushing's disease. Mitotane is a derivative of dichlorodipehyldichlororoethane (DDD) that specifically inhibits cells of the adrenal cortex. This adrenolytic action may prove effective in the long term suppression of hypercortisolism in the majority of patients with ACTH-dependent Cushing's syndrome [45,46]. Its mechanism of action also prevents the risk of escape phenomenon in response to the ACTH rise that occurs in Cushing's disease when plasma cortisol is decreased. However, its onset of action is slow (weeks or months), and the adverse effects associated with mitotane therapy (mainly digestive and neurological) require careful monitoring of drug levels, and it is routinely used in only a few centers. Etomidate is a non-opioid anesthetic that also induces adrenocortical suppression as one of its main side effects. In situations where rapid control of cortisol levels is required and oral therapy is problematic, iv etomidate therapy may be considered [47-49].

\section{Pituitary-directed therapy}

Pituitary-directed medical therapy targets the underlying cause of the disease, i.e. the ACTH-secreting tumor. A medical therapy that reverses tumor growth and lowers ACTH secretion to normal levels, thus normalizing the amount of cortisol being produced by the adrenal glands, would be a valuable therapeutic option for the management of Cushing's disease. Several pituitary-directed agents are under evaluation for the treatment of Cushing's disease, including peroxisome proliferator-activated receptor-gamma (PPAR- $\gamma$ ) agonists such as rosiglitazone and pioglitazone, dopamine agonists such as bromocriptine and cabergoline, and somatostatin analogues such as the investigational agent pasireotide.

PPAR- $\gamma$ is a member of the nuclear receptor super-family and functions as a transcription factor. PPAR- $\gamma$ ligands have been shown to inhibit cell growth in a number of tumor types [50], and rosiglitazone has demonstrated in vitro antiproliferative and apoptotic effects in corticotroph cells [51]. However, evaluation of normal pituitary tissue and pituitary tumors has shown poor expression of PPAR $-\gamma$ receptor in human pituitary tissue, no detection of a specific abnormality in PPAR- $\gamma$ expression in corticotroph tumors, poor immunocytochemical expression in both normal pituitary and pituitary adenomas, with only weak cytoplasmic staining [52]. In addition, the antiproliferative effect of rosiglitazone was shown only at very high doses and these were not blocked by a specific PPAR- $\gamma$ antagonist. In two small clinical studies of rosiglitazone in patients with Cushing's disease, normalization of UFC levels was achieved in $37.5 \%$ of patients (9/24), whereas in one study of pioglitazone in five patients with Cushing's disease, no patients achieved UFC normalization [50,53,54]. More data are required not only for efficacy, but also to address the long-term safety of rosiglitazone in these patients, particularly in light of the recent report that rosiglitazone is associated with a significant increase in the risk of myocardial infarction in patients with type 2 diabetes mellitus [55].

The dopamine $\mathrm{D}_{2}$ receptor is expressed in approximately $75 \%$ of corticotroph adenomas [56]. Both bromocriptine and cabergoline have shown in vitro inhibition of ACTH secretion in corticotroph tumor cells [56-58], suggesting they may be effective in patients with Cushing's disease. Miller and Crapo [42] summarized the results of small studies of patients with Cushing's disease $(\mathrm{n}=1-10)$ treated with bromocriptine. Of 23 patients 
with Cushing's disease treated with bromocriptine 1.25$30 \mathrm{mg} /$ day for 3-180 weeks, $42 \%$ achieved normalization of urine or plasma glucocorticoid levels [42], and ACTH levels decreased by more than $50 \%$ in $18 \%$ of patients. Subsequent consecutive studies on the effects of bromocriptine in patients with Cushing's disease did not confirm relevant efficacy. In a recent study of 20 patients with persistent Cushing's disease treated with cabergoline 1-3 mg/week post surgery, 7 patients (35\%) achieved normalized UFC levels after 3 months of treatment, and an additional $8(40 \%)$ achieved $\mathrm{a} \geq 25 \%$ reduction in UFC [59]. After 1 year of cabergoline 1-7 mg/week (median dose $6 \mathrm{mg} /$ week), 50\% of patients had normalized UFC, whereas at 2 years at a median dose of $3.5 \mathrm{mg} /$ week, $40 \%$ of patients had normalized UFC [59]. These promising results need confirming in larger studies in patients with Cushing's disease.

Human corticotroph adenomas also express multiple somatostatin receptor subtypes (sst receptors), with expression of sst $_{5}$ predominating [60]. Octreotide has high affinity for $\mathbf{s s t}_{2}$ and moderate affinity for $\mathrm{sst}_{5}$, and is mostly ineffective in Cushing's disease [61-63]. This lack of effect in corticotroph cells may be explained by downregulation of sst $_{2}$ receptors [64]. The novel multi-receptor tageted somatostatin analogue pasireotide has high affinity for $\mathrm{sst}_{1},{ }_{2},{ }_{3}$ and $\mathrm{sst}_{5}$. The functional activity of pasire-

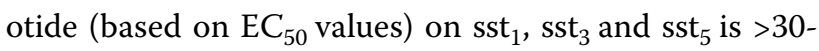
fold, 11-fold and 158-fold higher, respectively, than that of octreotide, and is approximately 7 -fold lower on $\mathrm{sst}_{2}$ [65]. In preclinical studies, pasireotide has shown significant inhibition of basal and stimulated ACTH release in human ACTH-secreting pituitary adenomas $[66,67]$ and in AtT-20 murine corticotroph tumor cells $[66,68]$, as well as significant inhibition of corticotropin-releasing hormone $(\mathrm{CRH})$-induced $\mathrm{ACTH}$ release in rats (Figure 1) $[69,70]$.

Results from a short-term, open-label Phase II study of pasireotide showed that it has the potential for being a pituitary-targeted medical treatment for Cushing's disease. Of 29 patients with de novo or persistent Cushing's disease who received pasireotide $600 \mu \mathrm{g}$ sc bid for 15 days, UFC levels decreased in $76 \%$ of patients and normalized in 17\% of patients (Figure 2) [71]. Adverse events associated with pasireotide were consistent with those observed with other somatostatin analogues, and included predominantly mild gastrointestinal events and mostly transient increases in blood glucose levels. To further determine the role of pasireotide in patients with de novo, persistent or recurrent Cushing's disease, a Phase III, randomized (between two doses), double-blind, multicenter trial is ongoing.

The potential for interaction between somatostatin and dopamine receptors to achieve greater suppression of

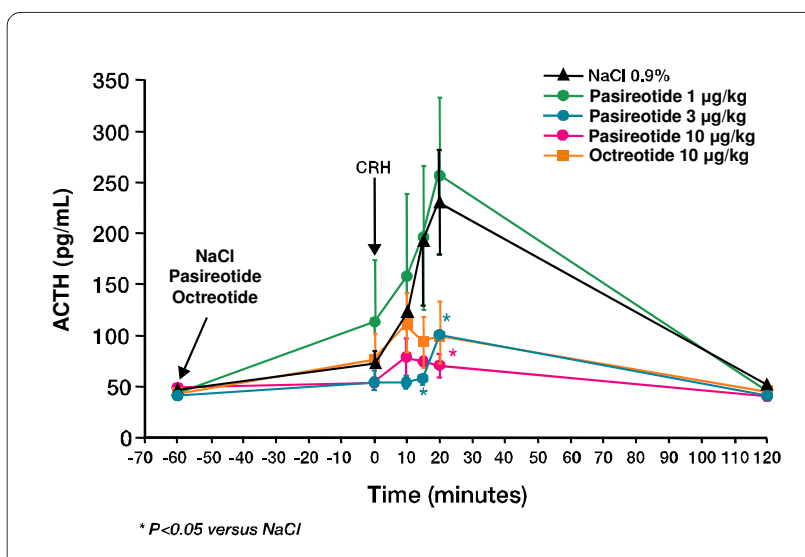

Figure 1 Regulation of CRH-induced secretion of ACTH in rats by pasireotide [70]. ${ }^{\odot} 2005$ Eur J Endocrinol. Reproduced with permission

ACTH levels is being explored with the development of chimeric agents. BIM 23A760 is one such agent, with high sst ${ }_{2}$ and $\mathrm{D}_{2}$ activity and moderate sst $_{5}$ activity [30,31]. Observation of a high co-expression of sst $_{5}$ and $\mathrm{D}_{2}$ in the majority of human corticotroph adenomas studied supports the potential for this agent in the treatment of Cushing's disease; clinical evaluation has not yet been performed [72].

\section{Other approaches}

Mifepristone is the only available glucocorticoid receptor antagonist. Although clinical data are currently limited in patients with Cushing's disease, early clinical data have demonstrated effective treatment of hypercortisolism, but close monitoring of potentially severe hypokalemia, hypertension, and clinical signs of adrenal insufficiency is required $[73,74]$.

Retinoic acid has been shown to be potentially useful in decreasing corticotroph secretion and proliferation in rodent models, and more recently in a dog model of Cushing's disease [75]. However, the effective dose used in dogs is high and clinical trial results in humans are not currently available.

\section{Conclusions}

Current adrenal-directed medical treatments for Cushing's disease have significant adverse effects and do not affect the underlying disease or restore normal HPA dynamics. Pituitary-directed medical therapy would instead target the underlying cause of the disease and should be pursued. Although PPAR- $\gamma$ agonists have demonstrated some efficacy in Cushing's disease, data are limited and there is currently no routine role for these agents. A small, short-term study suggests that cabergoline may be effective in treating a subset of patients with Cushing's disease, but more data are required to address the long-term safety of cabergoline in these patients. Pasireotide has shown promise as a pituitary-directed 


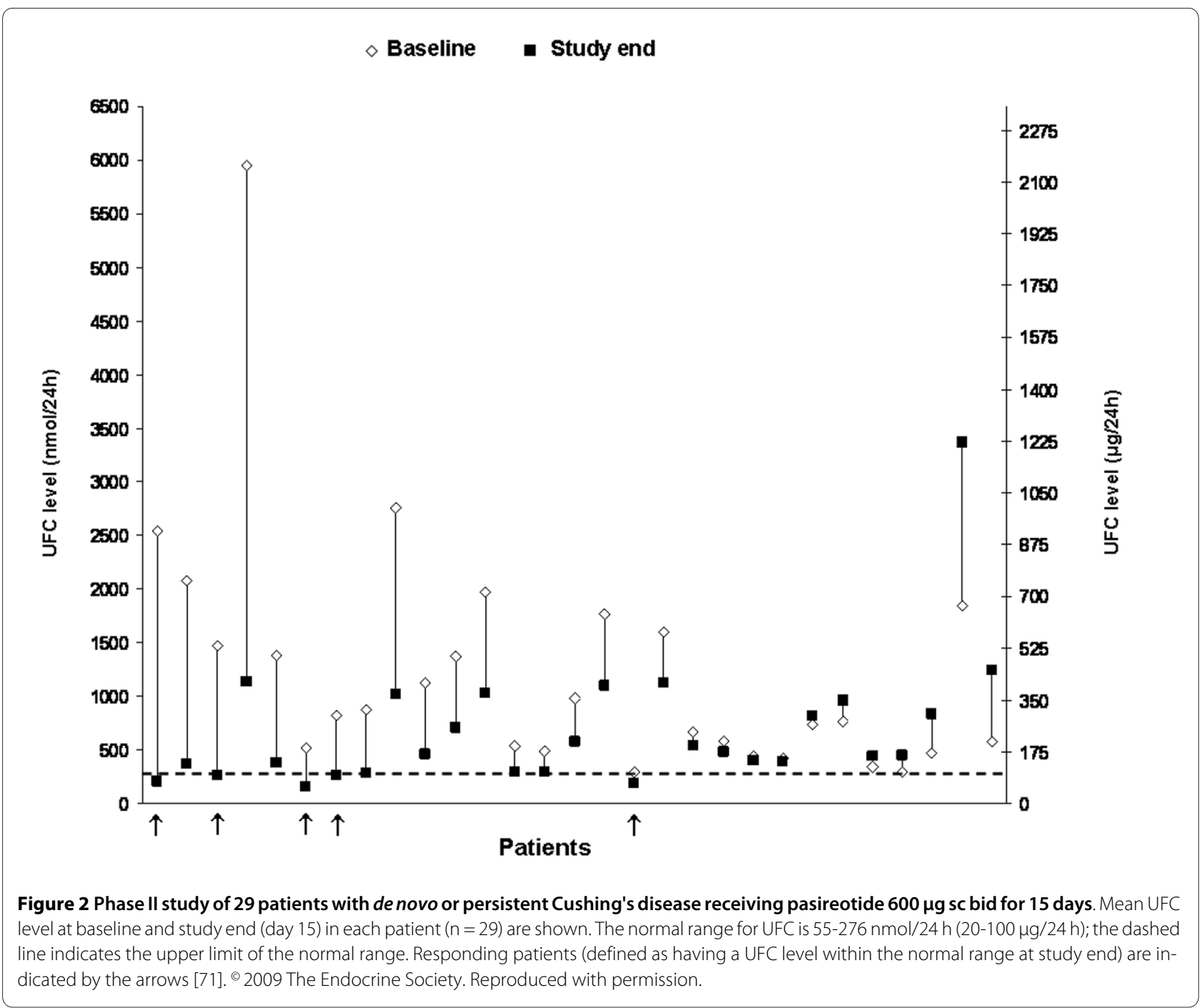

medical therapy in Cushing's disease in a Phase II study. Long-term efficacy and safety data from Phase III studies will determine whether pasireotide will have a role in the treatment of Cushing's disease.

\section{Management of acromegaly}

Acromegaly results from chronic hypersecretion of growth hormone $(\mathrm{GH})$ from a $\mathrm{GH}$-secreting pituitary adenoma in $>90 \%$ of patients [76]. GH induces the synthesis of insulin-like growth factor-1 (IGF-1) via hepatic GH receptors; elevated levels of GH and IGF-1 result in metabolic dysfunction and somatic growth. The classic clinical features of acromegaly include acral enlargement, sweating, headaches and glucose intolerance, and chronically unrestrained $\mathrm{GH}$ hypersecretion can lead to jaw prognathism, osteoarthritis, frontal bone bossing, diabetes mellitus, hypertension, and respiratory and cardiac failure [77-80]. Compared with the general population, patients with acromegaly have 2.4- to 4.8 -fold higher risk of mortality $[77,81,82]$.
The overall goals in the management of acromegaly are to eliminate morbidity and restore the increased mortality rate to normal age- and sex-adjusted rates [81-83]. These goals can be achieved using treatments that remove the tumor mass or reduce and/or control tumor growth, and restore GH secretion to normal. Reducing $\mathrm{GH}$ levels has been known to reduce mortality rates for some time [84], and the target GH level has been lowered progressively as more data are acquired. Currently, the criteria for cure of acromegaly are GH levels less than 0.4 $\mu \mathrm{g} / \mathrm{L}$ after an oral glucose load using a sensitive $\mathrm{GH}$ assay, and IGF-1 levels within the normal age- and sex-adjusted range [83]. Therapeutic goals in acromegaly are to reduce and/or stabilize tumor size, control plasma GH and IGF-1 levels (fasting GH levels $<2.5 \mu \mathrm{g} / \mathrm{L}$ and IGF-1 levels within the normal range), preserve pituitary function and prevent recurrences. Treatment modalities for acromegaly include transsphenoidal surgery, medical therapy and radiotherapy. 


\section{Pituitary surgery}

Transsphenoidal surgery is considered the first-line treatment for the initial management of patients with acromegaly, particularly patients with microadenomas who are likely to be cured after surgical resection [85]. Remission rates are highest in patients with microadenomas (75\%) and lowest in those with extrasellar macroadenomas; the remission rate in patients with a suprasellar macroadenoma and visual defects is approximately $33 \%$ [86]. When the surgery is performed by an experienced and pituitary dedicated neurosurgeon, transsphenoidal surgery has the potential to achieve biochemical cure and is associated with low mortality $(<0.1 \%)$ and morbidity $(<2 \%)$. However, approximately $70 \%$ of patients harbor macroadenomas; the majority of these patients will have persistent disease following surgery and will require adjuvant medical therapy or radiotherapy [86].

\section{Radiotherapy}

Conventional external beam radiotherapy has a slow onset of action, taking up to 15 years for maximal disease control, causes hypopituitarism in about $50 \%$ of patients and increases cerebrovascular mortality [87]. Stereotactic radiotherapy administered in a single dose (gamma knife, proton beam and LINAC) appears to have a faster onset of action with less hypopituitarism, although long-term data are limited $[88,89]$. Radiotherapy for persistent disease following surgery normalizes IGF-1 levels in up to $59 \%$ of patients depending on the series. By about 5 years after treatment, approximately one-third of patients will have developed pituitary deficiencies, and this is likely to increase with longer follow-up [90,91]. Indications for radiotherapy are post-surgical patients resistant or intolerant to medical therapy, and in recurrent, aggressive tumors.

\section{Medical therapy}

The three classes of medical therapy for acromegaly are based on receptor targets of the GH/IGF-1 axis: pituitary somatostatin receptor subtypes, pituitary dopamine $\mathrm{D}_{2}$ receptors, and peripheral GH receptors [76,85]. Approximately $90 \%$ of $\mathrm{GH}$-secreting adenomas express sst $_{2}$ and $\mathrm{sst}_{5}$; upon stimulation by a sst ligand, these receptors signal the pituitary to suppress the secretion of $\mathrm{GH}$, resulting in decreased hepatic IGF-1 synthesis. More recently, it has been suggested that a sst ligand may also act peripherally on the GH/IGF-1 axis by binding to somatostatin receptors on peripheral organs, such as hepatocytes in the liver, to inhibit the secretion of IGF-1 [92]. Dopamine agonists bind to pituitary $\mathrm{D}_{2}$ receptors, and although the exact mechanism by which dopamine agonists inhibit GH secretion from pituitary adenoma cells is not known, it is thought they act by decreasing the intracellular calcium concentration [85,93]. Thirdly, antagonism of peripheral $\mathrm{GH}$ receptors blocks the action of $\mathrm{GH}$ at the receptor which inhibits the synthesis of IGF-1 and lowers serum levels; GH levels remain elevated [94], but are blocked by the medication.

Somatostatin analogues are the first choice for the medical treatment of acromegaly in most patients. Octreotide and lanreotide are synthetic analogues of somatostatin that selectively bind to $s t_{2}$ and to a lesser extent sst $_{5}$ (Table 2), and have more prolonged pharmacological actions than the endogenous hormone.

Depot formulations of these analogues, octreotide LAR, lanreotide SR and lanreotide Autogel, have improved the clinical application of these compounds; octreotide LAR and lanreotide Autogel are administered once every 28 days, whereas lanreotide SR is administered once every 7-14 days.

Up to $75 \%$ of patients treated for $12-36$ months with octreotide LAR as adjuvant therapy achieve control of GH levels and/or IGF-1 levels [95]. In a meta-analysis by Freda et al, $57 \%$ and $67 \%$ of patients treated with octreotide LAR as adjuvant therapy achieved GH levels $<2.5$ $\mu \mathrm{g} / \mathrm{L}$ and IGF-1 normalization, respectively. In patients treated with lanreotide SR as adjuvant therapy, GH levels $<2.5 \mu \mathrm{g} / \mathrm{L}$ and IGF-1 normalization was achieved in $48 \%$ and $47 \%$ of patients, respectively [96]. There are fewer data available for lanreotide Autogel, but it has been shown to be as least effective as lanreotide SR when used as adjuvant therapy in patients with acromegaly [97].

First-line therapy with somatostatin analogues in patients with previously untreated acromegaly has received considerable attention since Newman et al showed that primary therapy with subcutaneous octreotide was as effective as adjuvant therapy with subcutaneous octreotide (following surgery or radiotherapy) at controlling GH and IGF-1 levels in patients with large or invasive tumors without visual or neurological distur-

Table 2: Somatostatin receptor subtype (sst) binding affinities of somatostatin and analogues in $\mathbf{n m o l} / \mathrm{L}$

\begin{tabular}{|c|c|c|c|c|c|}
\hline & sst $_{1}$ & sst $_{2}$ & sst $_{3}$ & sst $_{4}$ & sst $_{5}$ \\
\hline Somatostatin-14 & $0.1-2.3$ & $0.2-1.3$ & $0.3-1.6$ & $0.3-1.8$ & $0.2-0.9$ \\
\hline Octreotide & $280->1000$ & $0.4-2.1$ & $4.4-34.5$ & $>1000$ & $5.6-32$ \\
\hline Lanreotide & $180->1000$ & $0.5-1.8$ & $14-107$ & $66->1000$ & $0.6-17$ \\
\hline Pasireotide & 9.3 & 1.0 & 1.5 & $>1000$ & 0.16 \\
\hline
\end{tabular}


bances [98]. Most studies of first-line therapy of acromegaly with somatostatin analogues evaluated octreotide LAR, and recent studies have demonstrated that first-line therapy with octreotide LAR reduces GH and IGF-1 levels to a similar or greater extent than when administered after surgery and/or radiotherapy (Table 3) [99-106], and reduces pituitary tumor size (usually defined as a $10-25 \%$ reduction) in most patients (Table 3 and Figure 3) [99107]. Indeed, results from a prospective, long-term study (up to 9 years) in 67 patients with de novo acromegaly showed that $68.7 \%$ and $70.1 \%$ of patients treated with octreotide LAR as first-line therapy achieved GH levels $<2.5$ $\mu \mathrm{g} / \mathrm{L}$ and normal IGF-1 levels, respectively, and tumor volume decreased by $>25 \%$ in $82 \%$ of patients [104] .

In order to achieve the reversal of comorbidities and to decrease premature mortality in patients with acromegaly, long-term biochemical control is necessary. Recent studies have demonstrated the importance of regularly monitoring of GH and IGF-1 levels during treatment with somatostatin analogues, and that dose escalation should be performed if optimal control $(\mathrm{GH}<2.5 \mu \mathrm{g} / \mathrm{L}$ and normal IGF-1 levels) has not been achieved. In the recent study by Colao et al [103], in which 56 newly diagnosed patients received octreotide LAR as first-line therapy for 24 months, after 3 months of treatment with octreotide LAR $20 \mathrm{mg} / \mathrm{month}$ the dose was increased to $30 \mathrm{mg} /$ month in patients with inadequate control of GH $(\mathrm{GH}$ $>2.5 \mu \mathrm{g} / \mathrm{L}$ ) and/or IGF-1 levels. After a further 9 months, the dose was increased to $40 \mathrm{mg} / \mathrm{month}$ in those patients who still remained inadequately controlled. At the end of the 24-month study, $80 \%$ of patients had achieved GH and IGF-1 control, and mean GH and IGF-1 levels had decreased by $93 \%$ and $63 \%$, respectively. Moreover, $85 \%$

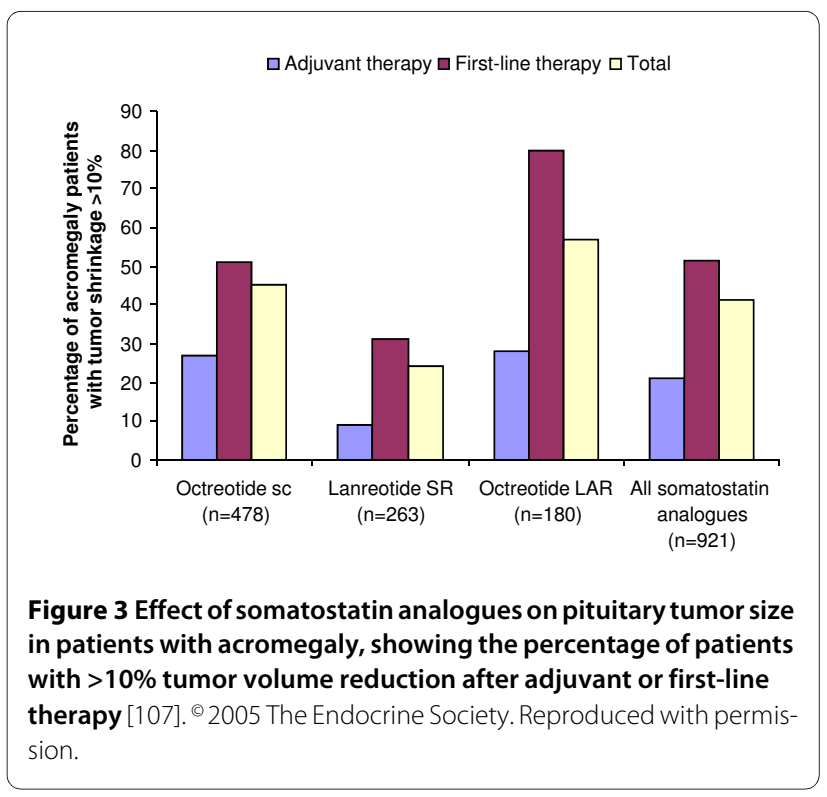

of the patients had achieved a tumor volume reduction of $>25 \%$ (Table 3) [103].

Suitable candidates for first-line therapy with somatostatin analogues might include patients with no risk of visual impairment from the tumor, patients with tumors unlikely to be controlled by surgery (eg lateral cavernous sinus invasion), patients who are at high surgical risk, and patients who decline surgery [83].

Pasireotide is also being evaluated in patients with acromegaly $[69,108,109]$. Based on the differences in binding affinity and functional activity of pasireotide and octreotide, it can be speculated that in cells and tissues that express sst receptors other than sst $_{2}$, pasireotide may

Table 3: Summary of results from studies of first-line therapy with octreotide LAR in patients with acromegaly

\begin{tabular}{|c|c|c|c|c|c|c|}
\hline Reference & No of pts & $\begin{array}{l}\text { Duration of } \\
\text { treatment }\end{array}$ & $\begin{array}{c}\text { Patients meeting } \\
\text { criterion for GH } \\
\text { control }(\%)\end{array}$ & $\begin{array}{l}\text { Patients with } \\
\text { IGF-1 } \\
\text { normalization } \\
\text { (\%) }\end{array}$ & $\begin{array}{c}\text { Mean tumor } \\
\text { shrinkage (\%) }\end{array}$ & $\begin{array}{c}\% \text { of patients with } \\
\text { significant tumor } \\
\text { shrinkage (definition of } \\
\text { significant) }\end{array}$ \\
\hline Colao et al 2001 [101] & 15 & $12-24$ months & 73 & 53 & 53 & $80(>20 \%)$ \\
\hline Amato et al 2002 [99] & 8 & 24 months & 50 & 50 & 34.8 & $100(>10 \%)$ \\
\hline Ayuk et al 2004 [100] & 25 & 48 weeks & 62 & 64 & NR & NR \\
\hline Jallad et al 2005 [105] & 28 & $6-24$ months & NR & 43 & NR & $76(>25 \%)$ \\
\hline Colao et al 2006 [102] & 34 & 6 months & 61 & 45.5 & 54 (median) & $74(>30 \%)$ \\
\hline Cozzi et al 2006 [104] & 67 & 6-108 months & 69 & 70 & 62 & $82(>25 \%)$ \\
\hline Mercado et al 2007 [106] & 68 & 48 weeks & 44 & 34 & 39 & 75 (>20\%) \\
\hline Colao et al 2007 [103] & 56 & 24 months & 86 & 84 & 68 & NR \\
\hline Colao et al 2008 [127] & 67 & 12 months & 52 & 58 & 49 & $85(>25 \%)$ \\
\hline Colao et al 2008 [128] & 40 & 48 weeks & NR & NR & 35 & $73(>20 \%)$ \\
\hline
\end{tabular}

$\mathrm{NR}=$ not reported 
have a stronger inhibitory effect on hormone secretion than octreotide [69]. Moreover, the multi-receptor binding profile of pasireotide suggests that it may be effective in patients with acromegaly resistant or refractory to octreotide. Results from a Phase II study show that pasireotide effectively controls GH and IGF-1 levels in patients with de novo or persistent/recurrent acromegaly, and significantly reduces pituitary tumor volume $[69,110,111]$. Results from an ongoing randomized, double-blind Phase III study comparing the efficacy of a long-acting release formulation of pasireotide with that of octreotide LAR in patients with acromegaly will help determine whether this agent is effective and safe.

Somatostatin analogues are well tolerated in most patients and treatment discontinuations due to adverse events are rare. The most common adverse events associated with somatostatin analogues are injection-site discomfort and erythema, gastrointestinal disturbances such as diarrhea, abdominal pain, flatulence, steatorrhea, nausea and vomiting, biliary sludge or gallstones, and transient hyperglycemia. However, most adverse events are mild or moderate and are transient [95].

Dopamine agonists were the first effective medical therapy for acromegaly, but have since been superseded by somatostatin analogues. Dopamine agonists can control GH and/or IGF-1 levels in 15-40\% of patients with acromegaly $[112,113]$. However, high doses are required and dopamine agonists are associated with nausea, postural hypotension and possible risk of cardiac valve regurgitation [13,14]. The addition of cabergoline to somatostatin analogue therapy may improve response in patients who otherwise are not fully controlled by maximal doses of somatostatin analogues, and in patients with adenomas co-secreting GH and prolactin [114]. The potential for dual somatostatin/dopamine activity in the treatment of patients with acromegaly will be addressed in studies of the chimeric dopamine/somatostatin receptor agonist BIM-23A760. In normal cynomolgus monkeys, BIM-23A760 has been seen to produce potent doserelated GH suppression, with no effect on circulating insulin or glucose levels [115].

Pegvisomant is the only GH receptor antagonist available; it has been shown in clinical trials to normalize IGF1 levels in up to $97 \%$ of patients, and can improve comorbidities such as insulin resistance [94,116-118]. Furthermore, because the efficacy of pegvisomant is not dependent on tumor somatostatin receptor expression, pegvisomant effectively inhibits IGF-1 secretion in patients who are non- or partial responders to somatostatin analogues. GH secretion is not inhibited during pegvisomant therapy and pegvisomant does not treat the tumor, necessitating regular monitoring for pituitary tumor growth [116-118]. Recent studies suggest that the addition of pegvisomant to somatostatin analogue ther- apy may increase the proportion of patients achieving normal IGF-1 levels, offset the lack of effect of pegvisomant on tumor growth, and improve the quality of life of patients with adequately controlled disease during somatostatin analogue monotherapy [119-121]. Although pegvisomant therapy is generally well tolerated, it is associated with elevated liver enzymes in a small proportion of patients and liver transaminase levels need to be monitored during therapy. Although rare, lipodystrophy at the site of injection has been reported during pegvisomant therapy, suggesting patients should undergo examination of the injection site [122]. Additional studies are required to ascertain the long-term safety of pegvisomant.

\section{Conclusions}

Surgery remains the first-line treatment option in patients with GH-secreting tumors. Somatostatin analogues may be used as first-line therapy in selected patients with large extrasellar tumors not amenable to surgical cure, in patients at high surgical risk, and in patients who decline surgery. Adjuvant therapy with somatostatin analogues is indicated after non-curative surgery and after radiotherapy when GH levels remain elevated. Pegvisomant is typically used in patients who have not responded to surgery and/or radiotherapy and other medical therapies, or in patients in whom glucose control may play a role in the selection of medication (depending on local approval), because it can improve insulin resistance. Dopamine agonists can be considered in patients with a prolactin co-secreting adenoma.

\section{Summary}

- First-line treatment of patients with prolactinomas is pharmacotherapy with dopamine agonists; surgery is indicated in the few patients with resistant adenomas who have compromise of the neurovisual apparatus or other adjacent neurological structures, or with contraindications to dopamine agonist use. Radiotherapy is indicated for selected patients, such as those who have not responded to medical or surgical treatment.

- First-line treatment of patients with Cushing's disease is pituitary surgery by an expert pituitary surgeon. Results from early, small studies evaluating pituitarydirected medical therapy, such as pasireotide and cabergoline, are encouraging, but further study is needed. Additional approaches include radiation therapy and adrenal-directed therapy, as well as bilateral laparoscopic adrenalectomy for immediate remission of hypercortisolemia when other approaches have failed and patients remain intolerant or incompletely treated.

- First-line treatment of patients with acromegaly is pituitary surgery when the outcome of the surgery is likely to be complete resection of the pituitary adenoma, or to debulk significant tumor, particularly if neurological 
structures are in jeopardy. Somatostatin analogues may be used as first-line therapy for acromegaly in selected patients with large extrasellar tumors not amenable to surgical cure, frail patients, patients at high surgical risk, and patients who decline surgery.

\section{Competing interests}

MB declares no competing interests. VB has research studies ongoing with support from Novartis, and speaker honoraria also from Novartis. BMKB has received research grants and/or consulting honoraria from Ipsen, Novartis and Pfizer. AC has received unrestricted grants by Ipsen, Italfarmaco, Novartis, and Pfizer for research programs in acromegaly, received lectures fees by Ipsen, Italfarmaco, Novartis, and Pfizer and has been a member of the Scientific Boards of Novartis and Ipsen. SP has received consulting fees from Novartis, and lecture honoraria from Novartis and Ipsen.

\section{Authors' contributions}

$B M K B, A C, S P, V S B$ and $M B$ all participated in an independent CME symposium at the 89th Annual Meeting of the Endocrine Society. This manuscript was developed directly from those presentations, which each author prepared him/herself. BMKB and SP directed the development of the manuscript, based on the content of the symposium presentations, with editorial assistance from Keri Wellington. All authors reviewed the manuscript and provided critical input. All authors read and approved the final manuscript.

\section{Acknowledgements}

The authors thank Keri Wellington, PhD, Mudskipper Bioscience, for medical editorial assistance with this manuscript. Financial support for medical editorial assistance was provided by Novartis Pharmaceuticals Corporation. The content of this review was not influenced by the pharmaceutical industry, and represents the content of an independent CME symposium at the 89th Annual Meeting of the Endocrine Society.

\section{Author Details}

'Neuroendocrine Clinical Center, Massachusetts General Hospital, Boston, USA, 2Dipartimento di Endocrinologia ed Oncologia Molecolare e Clinica, Università degli Studi di Napoli Federico II, Napoli, Italy, ${ }^{3}$ Division of Endocrinology, University of Duisburg-Essen, Essen, Germany, ${ }^{4}$ Department of Medicine, Cedars-Sinai Medical Center, David Geffen School of Medicine, University of California, Los Angeles, California, USA and ${ }^{5}$ Division of Endocrinology, Institute of Internal Medicine, Polytechnic University of Marche, Ancona, Italy

Received: 14 October 2009 Accepted: 17 May 2010

Published: 17 May 2010

\section{References}

1. Arafah BM, Nasrallah MP: Pituitary tumors: pathophysiology, clinical manifestations and management. Endocr Relat Cancer 2001, 8:287-305.

2. Ezzat S, Asa SL, Couldwell WT, Barr CE, Dodge WE, Vance ML, McCutcheon IE: The prevalence of pituitary adenomas: a systematic review. Cancer 2004, 101:613-619.

3. Daly AF, Rixhon M, Adam C, Dempegioti A, Tichomirowa MA, Beckers A: High prevalence of pituitary adenomas: a cross-sectional study in the province of Liege, Belgium. J Clin Endocrinol Metab 2006, 91:4769-4775.

4. Gillam MP, Molitch ME, Lombardi G, Colao A: Advances in the treatment of prolactinomas. Endocr Rev 2006, 27:485-534.

5. Colao A, Lombardi G: Growth-hormone and prolactin excess. Lancet 1998, 352:1455-1461.

6. Molitch ME: Dopamine resistance of prolactinomas. Pituitary 2003, 6:19-27.

7. Colao A, Di Sarno A, Landi ML, Scavuzzo F, Cappabianca P, Pivonello R, Volpe R, Di Salle F, Cirillo S, Annunziato L, Lombardi G:

Macroprolactinoma shrinkage during cabergoline treatment is greater in naive patients than in patients pretreated with other dopamine agonists: a prospective study in 110 patients. $J$ Clin Endocrino/ Metab 2000, 85:2247-2252

8. Freda PU, Andreadis Cl, Khandji AG, Khoury M, Bruce JN, Jacobs TP, Wardlaw SL: Long-term treatment of prolactin-secreting macroadenomas with pergolide. J Clin Endocrinol Metab 2000, 85:8-13.
9. Molitch ME, Elton RL, Blackwell RE, Caldwell B, Chang RJ, Jaffe R, Joplin G Robbins RJ, Tyson J, Thorner MO: Bromocriptine as primary therapy for prolactin-secreting macroadenomas: results of a prospective multicenter study. J Clin Endocrinol Metab 1985, 60:698-705.

10. Schlechte JA: Long-term management of prolactinomas. J Clin Endocrinol Metab 2007, 92:2861-2865.

11. Colao A, Di Sarno A, Cappabianca P, di Somma C, Pivonello R, Lombardi G: Withdrawal of long-term cabergoline therapy for tumoral and nontumoral hyperprolactinemia. N Eng/ J Med 2003, 349:2023-2033.

12. Webster J: A comparative review of the tolerability profiles of dopamine agonists in the treatment of hyperprolactinaemia and inhibition of lactation. Drug Saf 1996, 14:228-238.

13. Schade R, Andersohn F, Suissa S, Haverkamp W, Garbe E: Dopamine agonists and the risk of cardiac-valve regurgitation. N Eng/ J Med 2007, 356:29-38.

14. Zanettini R, Antonini A, Gatto G, Gentile R, Tesei S, Pezzoli G: Valvular heart disease and the use of dopamine agonists for Parkinson's disease. N Eng/J Med 2007, 356:39-46.

15. Colao A, Galderisi M, Di SA, Pardo M, Gaccione M, D'Andrea M, Guerra E, Pivonello R, Lerro G, Lombardi G: Increased prevalence of tricuspid regurgitation in patients with prolactinomas chronically treated with cabergoline. J Clin Endocrinol Metab 2008, 93:3777-3784.

16. Kars M, Delgado V, Holman ER, Feelders RA, Smit JW, Romijn JA, Bax JJ, Pereira AM: Aortic valve calcification and mild tricuspid regurgitation, but no clinical heart disease after 8 years of dopamine agonist therapy for prolactinoma. J Clin Endocrinol Metab 2008, 93:3348-3356.

17. Vallette S, Serri K, Rivera J, Santagata P, Delorme S, Garfield N, Kahtani N, Beauregard H, ris-jilwan N, Houde G, Serri O: Long-term cabergoline therapy is not associated with valvular heart disease in patients with prolactinomas. Pituitary 2008, 12:153-157.

18. Devin JK, Lakhani VT, Byrd BF III, Blevins LS Jr: Prevalence of valvular heart disease in a cohort of patients taking cabergoline for management of hyperprolactinemia. Endocr Pract 2008, 14:672-677.

19. Herring N, Szmigielski C, Becher H, Karavitaki N, Wass JA: Valvular heart disease and the use of cabergoline for the treatment of prolactinoma. Clin Endocrinol (Oxf) 2009, 70:104-108.

20. Wakil A, Rigby AS, Clark AL, Kallvikbacka-Bennett A, Atkin SL: Low dose cabergoline for hyperprolactinaemia is not associated with clinically significant valvular heart disease. Eur J Endocrinol 2008, 159:R11-R14.

21. Bogazzi F, Buralli S, Manetti L, Raffaelli V, Cigni T, Lombardi M, Boresi F, Taddei S, Salvetti A, Martino E: Treatment with low doses of cabergoline is not associated with increased prevalence of cardiac valve regurgitation in patients with hyperprolactinaemia. Int $J$ Clin Pract 2008, 62:1864-1869.

22. Lancellotti P, Livadariu E, Markov M, Daly AF, Burlacu MC, Betea D, Pierard $\mathrm{L}$, Beckers $\mathrm{A}$ : Cabergoline and the risk of valvular lesions in endocrine disease. Eur J Endocrinol 2008, 159:1-5.

23. Nachtigall LB, Valassi E, Lo J, McCarty D, Passeri J, Biller BM, Miller KK, Utz A, Grinspoon S, Lawson EA, Klibanski A: Gender effects on cardiac valvular function in hyperprolactinaemic patients receiving cabergoline: a retrospective study. Clin Endocrinol (Oxf) 2010, 72:53-58.

24. Bogazzi F, Manetti L, Raffaelli V, Lombardi M, Rossi G, Martino E: Cabergoline therapy and the risk of cardiac valve regurgitation in patients with hyperprolactinemia: a meta-analysis from clinical studies. J Endocrinol Invest 2008, 31:1119-1123.

25. Cannavo S, Bartolone L, Blandino A, Spinella S, Galatioto S, Trimarchi F: Shrinkage of a PRL-secreting pituitary macroadenoma resistant to cabergoline. J Endocrinol Invest 1999, 22:306-309.

26. Colao A, Annunziato L, Lombardi G: Treatment of prolactinomas. Ann Med 1998, 30:452-459.

27. Colao A, Sarno AD, Cappabianca P, Briganti F, Pivonello R, Somma CD, Faggiano A, Biondi B, Lombardi G: Gender differences in the prevalence, clinical features and response to cabergoline in hyperprolactinemia. Eur J Endocrinol 2003, 148:325-331.

28. Olafsdottir A, Schlechte J: Management of resistant prolactinomas. Nat Clin Pract Endocrinol Metab 2006, 2:552-561.

29. Hofland LJ, Hoek J Van Der, van Koetsveld PM, de Herder WW, Waaijers M, Sprij-Mooij D, Bruns C, Weckbecker G, Feelders R, Lely AJ van der, Beckers A, Lamberts SW: The novel somatostatin analog SOM230 is a potent inhibitor of hormone release by growth hormone- and prolactinsecreting pituitary adenomas in vitro. J Clin Endocrinol Metab 2004, 89:1577-1585. 
30. Jaquet P, Gunz G, Saveanu A, Barlier A, Dufour H, Taylor J, Dong J, Kim S, Moreau JP, Culler MD: BIM-23A760, a chimeric molecule directed towards somatostatin and dopamine receptors, vs universal somatostatin receptors ligands in $\mathrm{GH}$-secreting pituitary adenomas partial responders to octreotide. J Endocrinol Invest 2005, 28:21-27.

31. Gruszka A, Ren SG, Dong J, Culler MD, Melmed S: Regulation of growth hormone and prolactin gene expression and secretion by chimeric somatostatin-dopamine molecules. Endocrinology 2007, 148:6107-6114.

32. Fusco A, Gunz G, Jaquet P, Dufour H, Germanetti AL, Culler MD, Barlier A, Saveanu A: Somatostatinergic ligands in dopamine-sensitive and resistant prolactinomas. Eur J Endocrinol 2008, 158:595-603.

33. Arnaldi G, Angeli A, Atkinson AB, Bertagna X, Cavagnini F, Chrousos GP, Fava GA, Findling JW, Gaillard RC, Grossman AB, Kola B, Lacroix A, Mancini T, Mantero F, Newell-Price J, Nieman LK, Sonino N, Vance ML, Giustina A, Boscaro M: Diagnosis and complications of Cushing's syndrome: a consensus statement. J Clin Endocrinol Metab 2003, 88:5593-5602.

34. Findling JW, Raff H: Cushing's syndrome: important issues in diagnosis and management. J Clin Endocrinol Metab 2006, 91:3746-3753.

35. Biering $H$, Knappe $G$, Gerl H, Lochs $H$ : Prevalence of diabetes in acromegaly and Cushing syndrome. Acta Med Austriaca 2000, 27:27-31.

36. Atkinson AB, Kennedy A, Wiggam MI, McCance DR, Sheridan B: Longterm remission rates after pituitary surgery for Cushing's disease: the need for long-term surveillance. Clin Endocrinol (Oxf) 2005, 63:549-559.

37. Biller BMK, Grossman AB, Stewart PM, Melmed S, Bertagna X, Bertherat J, Buchfelder M, Colao A, Hermus AR, Hofland LJ, Klibanski A, Lacroix A, Lindsay JR, Newell-Price J, Nieman LK, Petersenn S, Sonino N, Stalla GK, Swearingen B, Vance ML, Wass JA, Boscaro M: Treatment of ACTHdependent Cushing's syndrome: a consensus statement. J Clin Endocrinol Metab 2008, 93:2454-2462.

38. Oyesiku NM: Stereotactic radiosurgery for Cushing disease: a review. Neurosurg Focus 2007, 23:E14.

39. Sonino N, Zielezny M, Fava GA, Fallo F, Boscaro M: Risk factors and longterm outcome in pituitary-dependent Cushing's disease. J Clin Endocrinol Metab 1996, 81:2647-2652.

40. Assie G, Bahurel H, Coste J, Silvera S, Kujas M, Dugue MA, Karray F, Dousset $B$, Bertherat J, Legmann $P$, Bertagna X: Corticotroph tumor progression after adrenalectomy in Cushing's Disease: A reappraisal of Nelson's Syndrome. J Clin Endocrinol Metab 2007, 92:172-179.

41. Nelson DH, MEAKIN JW, THORN GW: ACTH-producing pituitary tumors following adrenalectomy for Cushing's syndrome. Ann Intern Med 1960, 52:560-569.

42. Miller JW, Crapo L: The medical treatment of Cushing's syndrome. Endocr Rev 1993, 14:443-458.

43. Castinetti F, Morange I, Jaquet P, Conte-Devolx B, Brue T: Ketoconazole revisited: a preoperative or postoperative treatment in Cushing's disease. Eur J Endocrinol 2008, 158:91-99.

44. Verhelst JA, Trainer PJ, Howlett TA, Perry L, Rees LH, Grossman AB, Wass JA, Besser GM: Short and long-term responses to metyrapone in the medical management of 91 patients with Cushing's syndrome. Clin Endocrinol (Oxf) 1991, 35:169-178.

45. Schteingart DE, Tsao HS, Taylor Cl, McKenzie A, Victoria R, Therrien BA: Sustained remission of Cushing's disease with mitotane and pituitary irradiation. Ann Intern Med 1980, 92:613-619.

46. Luton JP, Mahoudeau JA, Bouchard P, Thieblot P, Hautecouverture M, Simon D, Laudat MH, Touitou Y, Bricaire H: Treatment of Cushing's disease by O,p'DDD. Survey of 62 cases. N Engl J Med 1979, 300:459-464

47. Krakoff J, Koch CA, Calis KA, Alexander RH, Nieman LK: Use of a parenteral propylene glycol-containing etomidate preparation for the long-term management of ectopic Cushing's syndrome. J Clin Endocrinol Metab 2001, 86:4104-4108.

48. Greening JE, Brain CE, Perry LA, Mushtaq I, Sales MJ, Grossman AB, Savage $\mathrm{MO}$ : Efficient short-term control of hypercortisolaemia by low-dose etomidate in severe paediatric Cushing's disease. Horm Res 2005, 64:140-143.

49. Drake WM, Perry LA, Hinds CJ, Lowe DG, Reznek RH, Besser GM: Emergency and prolonged use of intravenous etomidate to control hypercortisolemia in a patient with Cushing's syndrome and peritonitis. J Clin Endocrinol Metab 1998, 83:3542-3544.

50. Ambrosi B, Dall'Asta C, Cannavo S, Libe R, Vigo T, Epaminonda P, Chiodini I, Ferrero S, Trimarchi F, Arosio M, Beck-Peccoz P: Effects of chronic administration of PPAR-gamma ligand rosiglitazone in Cushing's disease. Eur J Endocrinol 2004, 151:173-178.

51. Heaney AP, Fernando M, Yong WH, Melmed S: Functional PPAR-gamma receptor is a novel therapeutic target for ACTH-secreting pituitary adenomas. Nat Med 2002, 8:1281-1287.

52. Emery MN, Leontiou C, Bonner SE, Merulli C, Nanzer AM, Musat M, Galloway M, Powell M, Nikookam K, Korbonits M, Grossman AB: PPARgamma expression in pituitary tumours and the functional activity of the glitazones: evidence that any anti-proliferative effect of the glitazones is independent of the PPAR-gamma receptor. Clin Endocrinol (Oxf) 2006, 65:389-395.

53. Pecori F Giraldi, Scaroni C, Arvat E, Martin M, Giordano R, Albiger N, Leao AA, Picu A, Mantero F, Cavagnini F: Effect of protracted treatment with rosiglitazone, a PPARgamma agonist, in patients with Cushing's disease. Clin Endocrinol (Oxf) 2006, 64:219-224.

54. Suri D, Weiss RE: Effect of pioglitazone on adrenocorticotropic hormone and cortisol secretion in Cushing's disease. J Clin Endocrinol Metab 2005, 90:1340-1346.

55. Nissen SE, Wolski K: Effect of rosiglitazone on the risk of myocardial infarction and death from cardiovascular causes. N Engl J Med 2007 356:2457-2471.

56. Pivonello R, Ferone D, de Herder WW, Kros JM, De Caro ML, Arvigo M, Annunziato L, Lombardi G, Colao A, Hofland LJ, Lamberts SW: Dopamine receptor expression and function in corticotroph pituitary tumors. J Clin Endocrinol Metab 2004, 89:2452-2462.

57. Adams EF, Ashby MJ, Brown SM, White MC, Mashiter K: Bromocriptine suppresses ACTH secretion from human pituitary tumour cells in culture by a dopaminergic mechanism. Clin Endocrinol (Oxf) 1981 $15: 479-484$

58. Stefaneanu L, Kovacs K, Horvath E, Buchfelder M, Fahlbusch R, Lancranjan $L$ : Dopamine D2 receptor gene expression in human adenohypophysial adenomas. Endocrine 2001, 14:329-336.

59. Pivonello R, De Martino MC, Cappabianca P, De LM, Faggiano A, Lombardi G, Hofland LJ, Lamberts SW, Colao A: The medical treatment of Cushing's disease: effectiveness of chronic treatment with the dopamine agonist cabergoline in patients unsuccessfully treated by surgery. J Clin Endocrinol Metab 2008, 94:223-230.

60. Ueberberg B, Tourne H, Redman A, Walz MK, Schmid KW, Mann K, Petersenn S: Differential expression of the human somatostatin receptor subtypes sst 1 to sst 5 in various adrenal tumors and normal adrenal gland. Horm Metab Res 2005, 37:722-728.

61. Woodhouse NJ, Dagogo-Jack S, Ahmed M, Judzewitsch R: Acute and long-term effects of octreotide in patients with ACTH-dependent Cushing's syndrome. Am J Med 1993, 95:305-308.

62. Invitti C, De Martin M, Brunani A, Piolini M, Cavagnini F: Treatment of Cushing's syndrome with the long-acting somatostatin analogue SMS 201-995 (sandostatin). Clin Endocrinol (Oxf) 1990, 32:275-281.

63. Ambrosi B, Bochicchio D, Fadin C, Colombo P, Faglia G: Failure of somatostatin and octreotide to acutely affect the hypothalamicpituitary-adrenal function in patients with corticotropin hypersecretion. J Endocrinol Invest 1990, 13:257-261.

64. Petersenn S, Rasch AC, Presch S, Beil FU, Schulte HM: Genomic structure and transcriptional regulation of the human somatostatin receptor type 2. Mol Cell Endocrinol 1999, 157:75-85

65. Schmid HA, Schoeffter P: Functional activity of the multiligand analog SOM230 at human recombinant somatostatin receptor subtypes supports its usefulness in neuroendocrine tumors. Neuroendocrinology 2004, 80(Suppl 1):47-50.

66. Hofland LJ, Hoek J Van Der, Feelders R, van Aken MO, van Koetsveld PM, Waaijers M, Sprij-Mooij D, Bruns C, Weckbecker G, de Herder WW, Beckers A, Lamberts SWJ: The multi-ligand somatostatin analogue SOM230 inhibits ACTH secretion by cultured human corticotroph adenomas via somatostatin receptor type 5. Eur J Endocrinol 2005, 152:645-654.

67. Batista DL, Zhang X, Gejman R, Ansell PJ, Zhou Y, Johnson SA, Swearingen B, Hedley-Whyte ET, Stratakis CA, Klibanski A: The effects of SOM230 on cell proliferation and adrenocorticotropin secretion in human corticotroph pituitary adenomas. J Clin Endocrinol Metab 2006 91:4482-4488.

68. Hoek J Van Der, Waaijers M, van Koetsveld PM, Sprij-Mooij D, Feelders RA, Schmid HA, Schoeffter P, Hoyer D, Cervia D, Taylor JE, Culler MD, Lamberts SW, Hofland LJ: Distinct functional properties of native somatostatin receptor subtype 5 compared with subtype 2 in the regulation of 
ACTH release by corticotroph tumour cells. Am J Physiol Endocrinol Metab 2005, 289:E278-E287.

69. Schmid HA: Pasireotide (SOM230): Development, mechanism of action and potential applications. Mol Cell Endocrinol 2008, 286:69-74

70. Silva AP, Schoeffter P, Weckbecker G, Bruns C, Schmid HA: Regulation of $\mathrm{CRH}$-induced secretion of $\mathrm{ACTH}$ and corticosterone by SOM230 in rats. Eur JEndocrinol 2005, 153:R7-R10.

71. Boscaro M, Ludlam WH, Atkinson B, Glusman JE, Petersenn S, Reincke M, Snyder P, Tabarin A, Biller BM, Findling J, Melmed S, Darby CH, Hu K, Wang $Y$, Freda PU, Grossman AB, Frohman LA, Bertherat J: Treatment of pituitary dependent Cushing's disease with the multi-receptor ligand somatostatin analog pasireotide (SOM230): A multicenter, phase II trial. J Clin Endocrinol Metab 2009, 94:115-122.

72. de Bruin C, Pereira AM, Feelders RA, Romijn JA, Roelfsema F, Sprij-Mooij DM, van Aken MO, Lelij AJ van der, de Herder WW, Lamberts SW, Hofland LJ: Coexpression of dopamine and somatostatin receptor subtypes in corticotroph adenomas. J Clin Endocrinol Metab 2009, 94:1118-1124.

73. Chu JW, Matthias DF, Belanoff J, Schatzberg A, Hoffman AR, Feldman D: Successful long-term treatment of refractory Cushing's disease with high-dose mifepristone (RU 486). J Clin Endocrinol Metab 2001, 86:3568-3573.

74. Castinetti F, Fassnacht M, Johanssen S, Terzolo M, Bouchard P, Chanson P, Do CC, Morange I, Pico A, Ouzounian S, Young J, Hahner S, Brue T, Allolio B, Conte-Devolx B: Merits and pitfalls of mifepristone in Cushing's syndrome. Eur J Endocrinol 2009, 160:1003-1010.

75. Castillo V, Giacomini D, Paez-Pereda M, Stalla J, Labeur M, Theodoropoulou M, Holsboer F, Grossman AB, Stalla GK, Arzt E: Retinoic acid as a novel medical therapy for Cushing's disease in dogs. Endocrinology 2006, 147:4438-4444.

76. Melmed S: Medical progress: Acromegaly. N Engl J Med 2006, 355:2558-2573.

77. Rajasoorya C, Holdaway IM, Wrightson P, Scott DJ, lbbertson HK Determinants of clinical outcome and survival in acromegaly. Clin Endocrinol (Oxf) 1994, 41:95-102.

78. Orme SM, McNally RJ, Cartwright RA, Belchetz PE: Mortality and cancer incidence in acromegaly: a retrospective cohort study. United Kingdom Acromegaly Study Group. J Clin Endocrinol Metab 1998, 83:2730-2734

79. Clayton RN: New developments in the management of acromegaly. Should we achieve absolute biochemical cure? J Endocrinol 1997, 155(Suppl 1):S23-S29

80. Melmed S: Acromegaly and cancer: not a problem? J Clin Endocrinol Metab 2001, 86:2929-2934.

81. Holdaway IM, Rajasoorya RC, Gamble GD: Factors influencing mortality in acromegaly. J Clin Endocrinol Metab 2004, 89:667-674.

82. Kauppinen-Makelin R, Sane T, Reunanen A, Valimaki MJ, Niskanen L, Markkanen H, Loyttyniemi E, Ebeling T, Jaatinen P, Laine H, Nuutila P, Salmela P, Salmi J, Stenman UH, Viikari J, Voutilainen E: A nationwide survey of mortality in acromegaly. J Clin Endocrinol Metab 2005, 90:4081-4086

83. Melmed S, Casanueva F, Cavagnini F, Chanson P, Frohman LA, Gaillard R, Ghigo E, Ho K, Jaquet P, Kleinberg D, Lamberts S, Laws E, Lombardi G, Sheppard MC, Thorner M, Vance ML, Wass JA, Giustina A: Consensus statement: medical management of acromegaly. Eur J Endocrinol 2005, 153:737-740.

84. Christy NP: Choosing the best treatment for acromegaly. JAMA 1982, 247:1320.

85. AACE Acromegaly Guidelines Task Force: AACE Medical Guidelines for Clinical Practice for the diagnosis and treatment of acromegaly. Endocr Pract 2004, 10:213-225.

86. Nomikos P, Buchfelder M, Fahlbusch R: The outcome of surgery in 668 patients with acromegaly using current criteria of biochemical 'cure'. Eur JEndocrinol 2005, 152:379-387.

87. Jenkins PJ, Bates P, Carson MN, Stewart PM, Wass JA: Conventional pituitary irradiation is effective in lowering serum growth hormone and insulin-like growth factor-I in patients with acromegaly. J Clin Endocrinol Metab 2006, 91:1239-1245.

88. Attanasio R, Epaminonda P, Motti E, Giugni E, Ventrella L, Cozzi R, Farabola M, Loli P, Beck-Peccoz P, Arosio M: Gamma-knife radiosurgery in acromegaly: a 4-year follow-up study. J Clin Endocrinol Metab 2003, 88:3105-3112
89. Castinetti F, Nagai M, Dufour H, Kuhn JM, Morange I, Jaquet P, ConteDevolx B, Regis J, Brue T: Gamma knife radiosurgery is a successful adjunctive treatment in Cushing's disease. Eur J Endocrinol 2007, 156:91-98.

90. Jagannathan J, Sheehan JP, Pouratian N, Laws ER Jr, Steiner L, Vance ML: Gamma knife radiosurgery for acromegaly: outcomes after failed transsphenoidal surgery. Neurosurgery 2008, 62:1262-1269.

91. Petit JH, Biller BM, Coen JJ, Swearingen B, Ancukiewicz M, Bussiere M, Chapman P, Klibanski A, Loeffler JS: Proton stereotactic radiosurgery in management of persistent acromegaly. Endocr Pract 2007, 13:726-734

92. Murray RD, Kim K, Ren SG, Chelly M, Umehara Y, Melmed S: Central and peripheral actions of somatostatin on the growth hormone-IGF-I axis. J Clin Invest 2004, 114:349-356.

93. Nishina Y, Takano K, Yasufuku-Takano J, Teramoto A, Fujita T: Mechanism of $\mathrm{D}(2)$ agonist-induced inhibition of $\mathrm{GH}$ secretion from human $\mathrm{GH}$ secreting adenoma cells. Endocr $J$ 2005, 52:775-779.

94. Freda PU: Pegvisomant therapy for acromegaly. Exp Rev Endcrinol Metab 2006, 1:489-498.

95. Freda PU: Somatostatin analogs in acromegaly. J Clin Endocrinol Metab 2002, 87:3013-3018.

96. Freda PU, Katznelson L, Lely AJ van der, Reyes CM, Zhao S, Rabinowitz D: Long-acting somatostatin analog therapy of acromegaly: a metaanalysis. J Clin Endocrinol Metab 2005, 90:4465-4473.

97. Caron P, Beckers A, Cullen DR, Goth MI, Gutt B, Laurberg P, Pico AM, Valimaki M, Zgliczynski W: Efficacy of the new long-acting formulation of lanreotide (lanreotide Autogel) in the management of acromegaly. J Clin Endocrinol Metab 2002, 87:99-104

98. Newman CB, Melmed S, George A, Torigian D, Duhaney M, Snyder P, Young W, Klibanski A, Molitch ME, Gagel R, Sheeler L, Cook D, Malarkey W, Jackson I, Vance ML, Barkan A, Frohman L, Kleinberg DL: Octreotide as primary therapy for acromegaly. J Clin Endocrinol Metab 1998, 83:3034-3040

99. Amato G, Mazziotti G, Rotondi M, lorio S, Doga M, Sorvillo F, Manganella G, Di Salle F, Giustina A, Carella C: Long-term effects of lanreotide SR and octreotide LAR on tumour shrinkage and GH hypersecretion in patients with previously untreated acromegaly. Clin Endocrinol (Oxf) 2002, 56:65-71.

100. Ayuk J, Stewart SE, Stewart PM, Sheppard MC: Efficacy of Sandostatin LAR (long-acting somatostatin analogue) is similar in patients with untreated acromegaly and in those previously treated with surgery and/or radiotherapy. Clin Endocrinol (Oxf) 2004, 60:375-381.

101. Colao A, Ferone D, Marzullo P, Cappabianca P, Cirillo S, Boerlin V, Lancranjan I, Lombardi G: Long-term effects of depot long-acting somatostatin analog octreotide on hormone levels and tumor mass in acromegaly. J Clin Endocrinol Metab 2001, 86:2779-2786.

102. Colao A, Pivonello R, Rosato F, Tita P, De Menis E, Barreca A, Ferrara R, Mainini F, Arosio M, Lombardi G: First-line octreotide-LAR therapy induces tumor shrinkage and controls hormone excess in patients with acromegaly: results from an open, prospective, multicentre trial. Clin Endocrinol (Oxf) 2006, 64:342-351.

103. Colao A, Pivonello R, Auriemma RS, Galdiero M, Savastano S, Lombardi G Beneficial effect of dose escalation of Octreotide-LAR as first-line therapy in patients with acromegaly. Eur J Endocrinol 2007, 157:579-587.

104. Cozzi R, Montini M, Attanasio R, Albizzi M, Lasio G, Lodrini S, Doneda P, Cortesi L, Pagani G: Primary treatment of acromegaly with octreotide LAR: a long-term (up to 9 years) prospective study of its efficacy in the control of disease activity and tumor shrinkage. J Clin Endocrinol Metab 2006, 91:1397-1403.

105. Jallad RS, Musolino NR, Salgado LR, Bronstein MD: Treatment of acromegaly with octreotide-LAR: extensive experience in a Brazilian institution. Clin Endocrinol (Oxf) 2005, 63:168-175.

106. Mercado M, Borges F, Bouterfa H, Chang TC, Chervin A, Farrall AJ, Patocs A, Petersenn S, Podoba J, Safari M, Wardlaw J: A prospective, multicentre study to investigate the efficacy, safety and tolerability of octreotide LAR (long-acting repeatable octreotide) in the primary therapy of patients with acromegaly. Clin Endocrinol (Oxf) 2007, 66:859-868.

107. Bevan JS: The antitumoral effects of somatostatin analog therapy in acromegaly. J Clin Endocrinol Metab 2005, 90:1856-1863.

108. Hoek J Van Der, de Herder WW, Feelders RA, Lely AJ van der, Uitterlinden P, Boerlin V, Bruns C, Poon KW, Lewis I, Weckbecker G, Krahnke T, Hofland $L$, Lamberts SW: A single-dose comparison of the acute effects 
between the new somatostatin analog SOM230 and octreotide in acromegalic patients. J Clin Endocrinol Metab 2004, 89:638-645.

109. Hoek J Van Der, Lelij AJ van der, Feelders RA, de Herder WW, Uitterlinden P, Poon KW, Boerlin V, Lewis I, Krahnke T, Hofland LJ, Lamberts SW: The somatostatin analogue SOM230, compared with octreotide, induces differential effects in several metabolic pathways in acromegalic patients. Clin Endocrinol (Oxf) 2005, 63:176-184.

110. Farrall A, Glusman JE, Ruffin M, Petersenn S: Pasireotide (SOM230) effectively reduces pituitary tumor volume in patients with active acromegaly: preliminary 6-month results from a Phase II extension study. Endocrine Abstracts 2008, 16:OC1.4.

111. Petersenn S, Schopohl J, Barkan A, Mohideen P, Colao A, Abs R, Buchelt A, Ho YY, Hu K, Farrall AJ, Melmed S, Biller BM: Pasireotide (SOM230) demonstrates efficacy and safety in patients with acromegaly: randomized, multicenter, Phase II trial. J Clin Endocrinol Metab 2010 in press.

112. Abs R, Verhelst J, Maiter D, Van Acker K, Nobels F, Coolens JL, Mahler C, Beckers A: Cabergoline in the treatment of acromegaly: a study in 64 patients. J Clin Endocrinol Metab 1998, 83:374-378.

113. Cozzi R, Attanasio R, Barausse M, Dallabonzana D, Orlandi P, Da RN, Branca V, Oppizzi G, Gelli D: Cabergoline in acromegaly: a renewed role for dopamine agonist treatment? Eur J Endocrinol 1998, 139:516-521.

114. Cozzi R, Attanasio R, Lodrini S, Lasio G: Cabergoline addition to depot somatostatin analogues in resistant acromegalic patients: efficacy and lack of predictive value of prolactin status. Clin Endocrinol (Oxf) 2004, 61:209-215.

115. Culler MD, Dong JZ, Taylor JE, et al:: The somatostatin-dopamine chimeric molecule, BIM-23A760, does not induce the insulin/glycemic effects observed with individual somatostatin or dopamine agonists in cynomolgus monkeys (Macaca fascicularis). 12th meeting of the European Neuroendocrine Association, abstract OC2 112006.

116. Jehle S, Reyes CM, Sundeen RE, Freda PU: Alternate-day administration of pegvisomant maintains normal serum insulin-like growth factor-I levels in patients with acromegaly. J Clin Endocrinol Metab 2005, 90:1588-1593

117. Trainer PJ, Drake WM, Katznelson L, Freda PU, Herman-Bonert V, Lely AJ van der, Dimaraki EV, Stewart PM, Friend KE, Vance ML, Besser GM, Scarlett JA, Thorner MO, Parkinson C, Klibanski A, Powell JS, Barkan AL, Sheppard MC, Malsonado M, Rose DR, Clemmons DR, Johannsson G, Bengtsson BA, Stavrou S, Kleinberg DL, Cook DM, Phillips LS, Bidlingmaier M, Strasburger CJ, Hackett S, et al:: Treatment of acromegaly with the growth hormonereceptor antagonist pegvisomant. N Engl J Med 2000, 342:1171-1177.

118. Lely AJ van der, Hutson RK, Trainer PJ, Besser GM, Barkan AL, Katznelson L, Klibanski A, Herman-Bonert V, Melmed S, Vance ML, Freda PU, Stewart PM, Friend KE, Clemmons DR, Johannsson G, Stavrou S, Cook DM, Phillips LS, Strasburger CJ, Hackett S, Zib KA, Davis RJ, Scarlett JA, Thorner MO: Longterm treatment of acromegaly with pegvisomant, a growth hormone receptor antagonist. Lancet 2001, 358:1754-1759.

119. Feenstra J, de Herder WW, ten Have SM, Beld AW van den, Feelders RA Janssen JA, Lely AJ van der: Combined therapy with somatostatin analogues and weekly pegvisomant in active acromegaly. Lancet 2005, 365:1644-1646.

120. Neggers SJ, van Aken MO, Janssen JA, Feelders RA, de Herder WW, Lely AJ van der: Long-term Efficacy and Safety of Combined Treatment of Somatostatin Analogs and Pegvisomant in Acromegaly. J Clin Endocrinol Metab 2007, 92:4598-4601.

121. Neggers SJ, van Aken MO, de Herder WW, Feelders RA, Janssen JA, Badia $X$, Webb SM, Lely AJ van der: Quality of Life in Acromegalic Patients during Long-Term Somatostatin Analog Treatment with and without Pegvisomant. J Clin Endocrinol Metab 2008, 93:3853-3859.

122. Bonert VS, Kennedy L, Petersenn S, Barkan A, Carmichael J, Melmed S: Lipodystrophy in patients with acromegaly receiving pegvisomant. $J$ Clin Endocrinol Metab 2008, 93:3515-3518.

123. Bruns C, Lewis I, Briner U, Meno-Tetang G, Weckbecker G: SOM230: a novel somatostatin peptidomimetic with broad somatotropin release inhibiting factor (SRIF) receptor binding and a unique antisecretory profile. Eur J Endocrinol 2002, 146:707-716.

124. Hofland LJ, Lamberts SW: The pathophysiological consequences of somatostatin receptor internalization and resistance. Endocr Rev 2003, 24:28-47.

125. Jaquet P, Gunz G, Saveanu A, Dufour H, Taylor J, Dong J, Kim S, Moreau JP, Enjalbert A, Culler MD: Efficacy of chimeric molecules directed towards multiple somatostatin and dopamine receptors on inhibition of $\mathrm{GH}$ and prolactin secretion from $\mathrm{GH}$-secreting pituitary adenomas classified as partially responsive to somatostatin analog therapy. Eur J Endocrinol 2005, 153:135-141.

126. Patel YC: Somatostatin and its receptor family. Front Neuroendocrinol 1999, 20:157-198

127. Colao A, Pivonello R, Auriemma RS, Galdiero M, Savastano S, Grasso LF Lombardi G: Growth hormone-secreting tumor shrinkage after 3 months of octreotide-LAR therapy predicts the response at 12 months. J Clin Endocrinol Metab 2008, 93:3436-3442.

128. Colao A, Cappabianca P, Caron P, De ME, Farrall AJ, Gadelha MR, Hmissi A, Rees A, Reincke M, Safari M, T'Sjoen G, Bouterfa H, Cuneo RC: Octreotide LAR vs. surgery in newly diagnosed patients with acromegaly: a randomized, open-label, multicentre study. Clin Endocrinol (Oxf) 2009, 70:757-768

Pre-publication history

The pre-publication history for this paper can be accessed here: http://www.biomedcentral.com/1472-6823/10/10/prepub

doi: $10.1186 / 1472-6823-10-10$

Cite this article as: Biller et al., Prolactinomas, Cushing's disease and acromegaly: debating the role of medical therapy for secretory pituitary adenomas BMC Endocrine Disorders 2010, 10:10

\section{Submit your next manuscript to BioMed Centra and take full advantage of:}

- Convenient online submission

- Thorough peer review

- No space constraints or color figure charges

- Immediate publication on acceptance

- Inclusion in PubMed, CAS, Scopus and Google Scholar

- Research which is freely available for redistribution 